\title{
Investigation into the Effects of Turbulent Air Flow on Stall of a NACA 2412 Airfoil Using Spalart-Allmaras Turbulence Model in STARCCM+
}

\author{
Zhexin Wang, Yuwen Su \\ National Aerospace University "Kharkiv Aviation Institute" - KhAI University
}

\begin{abstract}
The simulation results of the air flow around NACA 2412 airfoil in STARCCM+ are submitted. The 9 groups of comparative experiments were simulated at 9 angles of attack: 0, 10, 13, 14, 15, 16, 18, 20, 30 degrees. By analyzing the air flow near the upper surface airfoil, the relationship between the generation condition of separation vortex and the angle of attack and the law of change of angle of attack and lift force were obtained. Finding the range of angle of attack for the stall, the angle of attack with maximum lift effectiveness was determined. Keywords: Stall, Angle of Attack, Lift force, NACA 2412, STARCCM+.
\end{abstract}

Air travel has become an increasingly popular way of travel, but accidents have occasionally occurred. Ensuring flight safety becomes the most important issue for the aviation industry. Aircraft stalls account for a large proportion of air crashes. On November 21, 2004, China Eastern Airlines Yunnan Company's CRJ-200 B-3072 aircraft carried out the MU5210 mission from Baotou to Shanghai and crashed near Baotou Airport (1), resulting in 55 people casualties, with direct economic losses of 180 million Yuan. The cause of the accident (2) was that the critical angle of attack (AoA) of the airfoil stall was reduced due to airfoil pollution during the takeoff of the aircraft. The aircraft stalled just after the plane left the ground, and the pilot failed to recover from the stall until the plane crashed.

When the AoA of the airfoil reaches a certain level, the airfoil is equivalent to a slab erected in the airflow. Because the angle is too large, the airflow lines around the upper airfoil cannot be continuous, and separation will occur. After driven, flow backwards and downwards, it will eventually be rolled into a closed vortex, called a separation vortex as shown in Figure 1 blue area. The pressure (3) in a vortex rotating like this is constant, and its pressure is equal to the pressure of the airflow above the vortex. Therefore, the pressure difference between the upper and lower airfoil surfaces will be much smaller, and the lift of the airfoil will be reduced than before.

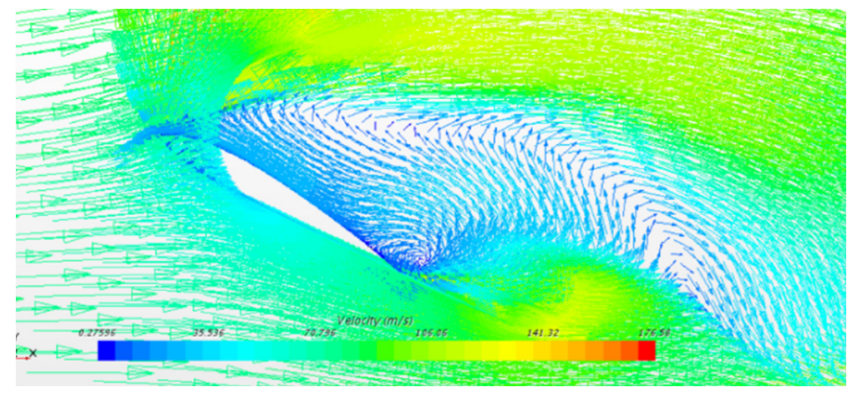

Fig. 1. Separation vortex

The aim of the project is to analyze the stall AoA and the relationship between AoA and lift force. obtain the relationship between the generation condition of separation vortex and the AoA and the law of change of AoA and lift force. Fluid flow is governed by the laws of physical conservation. The basic conservation laws include conservation of mass, conservation of momentum, and conservation of energy. If the flow is turbulent, the system also follows additional turbulent transport equations.

The law of conservation of mass is given by (4):

$$
\frac{\partial \rho}{\partial t}+\nabla \cdot(\rho \vec{V})=0
$$

The law of conservation of momentum are given by (4): 


$$
\begin{aligned}
& \frac{\partial\left(\rho_{u}\right)}{\partial t}+\nabla \cdot(\rho u \vec{V})=-\frac{\partial p}{\partial x}+\frac{\partial \tau_{x x}}{\partial x}+\frac{\partial \tau_{y x}}{\partial y}+\frac{\partial \tau_{z x}}{\partial z}+\rho f_{x}, \\
& \frac{\partial\left(\rho_{u}\right)}{\partial t}+\nabla \cdot(\rho u \vec{V})=-\frac{\partial p}{\partial y}+\frac{\partial \tau_{x y}}{\partial x}+\frac{\partial \tau_{y y}}{\partial y}+\frac{\partial \tau_{z y}}{\partial z}+\rho f_{y}, \\
& \frac{\partial\left(\rho_{u}\right)}{\partial t}+\nabla \cdot(\rho u \vec{V})=-\frac{\partial p}{\partial z}+\frac{\partial \tau_{x z}}{\partial x}+\frac{\partial \tau_{y z}}{\partial y}+\frac{\partial \tau_{z z}}{\partial z}+\rho f_{z},
\end{aligned}
$$

Energy conservation law is given by (4):

$$
\frac{\partial}{\partial t}\left[\rho\left(\mathrm{e}+\frac{V^{2}}{2}\right)\right]=\nabla \cdot\left[\rho\left(\mathrm{e}+\frac{V^{2}}{2}\right) \vec{V}\right],
$$

There are four types of turbulence model can be chosen: K-Epsilon Turbulence, K-Omega Turbulence, Reynolds Stress Turbulence, and Spalart-Allmaras Turbulence. In this case, the SpalartAllmaras Turbulence is chosen for simulation. The equation is given by (4):

$$
\frac{\partial \vec{v}}{\partial t}+\vec{u}_{j} \frac{\partial \vec{v}}{\partial x_{j}}=C_{b 1} \vec{S} \vec{V}+\frac{1}{\sigma}\left[\frac{\partial}{\partial x_{j}}\left((v+\vec{v}) \frac{\partial \vec{v}}{\partial x_{j}}\right)+C_{b 2} \frac{\partial \vec{v}}{\partial x_{j}} \frac{\partial \vec{v}}{\partial x_{j}}\right]-C_{w 1} f_{w}\left(\frac{\vec{v}}{d}\right)^{2},
$$

Suppose the aircraft is flying at $300 \mathrm{~km} / \mathrm{h}=83.33 \mathrm{~m} / \mathrm{s}$, and the air density is $1.18415 \mathrm{~kg} / \mathrm{m}^{3}$, the dynamic viscosity is $1.85508 \mathrm{E}-5$ Pa.s. So, Reynolds Number is:

$$
R e=\frac{\rho_{v b}}{\mu}=\frac{1.18415 \cdot 83.33 \cdot 1}{1.85508 \cdot 10^{-5}}=5.319 \cdot 10^{6},
$$

In the simulation, the boundary conditions are shown as fellow. For inlet: velocity magnitude is $83.33 \mathrm{~m} / \mathrm{s}^{2}$. Velocity specification is magnitude+direction. The turbulent viscosity ratio is 10 . Flow direction specification is boundary+normal. Turbulence specification is turbulent viscosity ratio. For outlet: turbulent viscosity ratio is 10 . Outlet pressure is $0 \mathrm{~Pa}$. For airfoil: shear stress specification: no-slip. To prevent stalls, the lift force should be maintained at a higher value. STARCCM + was used to simulate the airflow of the NACA 2412 wing. Nine groups of simulation experiments were performed, and the angles of attack of the nine groups were $0,10,13,14,15,16,18,20$, and 30 degrees, respectively. Obtain the law of change of AoA and lift force. The lift force in different AoA is shown in Figure 2.

To analysis the reason AoA affects lift force, the air flow velocity near the airfoil at 9 different AoA should be observed. The air flow velocity simulation results are shown in Figure 3. It can be seen that when AoA is less than 13 degrees, airfoil upper surface separation vortex does not appear, and the air flow velocity difference between the upper and lower airfoil increases with the AoA increase. This is the reason why the lift force increases significantly. When AoA is more than 14 degrees and less than 18 degrees, separation vortex starts appearing at the end of airfoil upper surface, but air velocity still increases wherein most of the upper surface of the airfoil. Separation vortex influences lift force slightly. So, within this angle range, the increasing velocity plays an important role than separation vortex, the lift force can increase continue. Once, the AoA is over 18 degrees, the separation vortex getting bigger as the AoA increase. The separation vortex plays a leading role in lift force gradually with the AoA increase. So, the lift force starts to decrease and the plane stall gradually. When AoA is over 30 degrees, the separation vortex appears on the whole airfoil upper surface, the lift force value is very low compared with lift force before stall. 


\section{Секція Авіаційна та ракетно-космічна техніка}
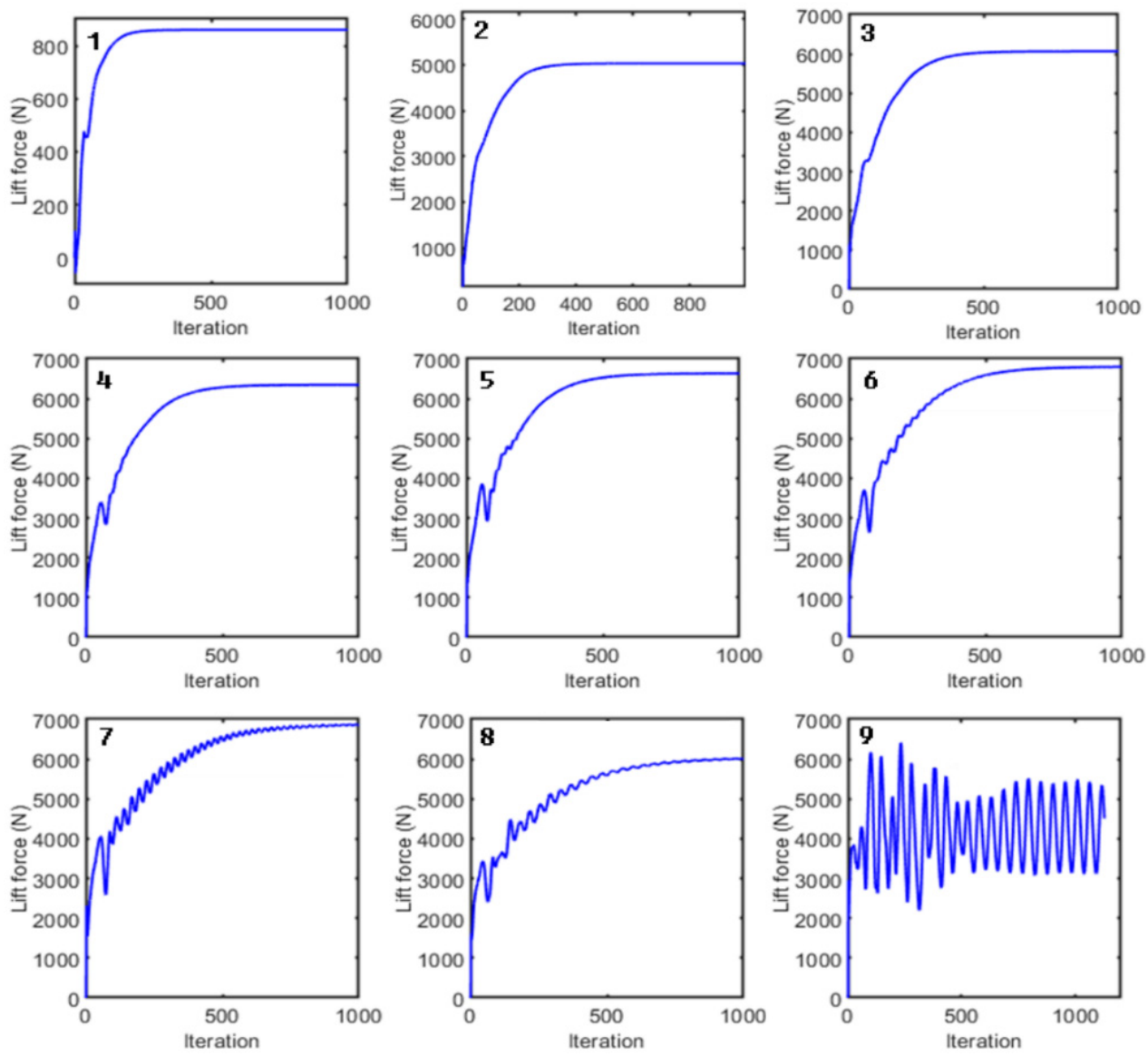

Fig. 2. Lift force at different AoA: 1-9 are AoA of 0, 10, 13, 14, 15, 16, 18, 20, 30 degrees

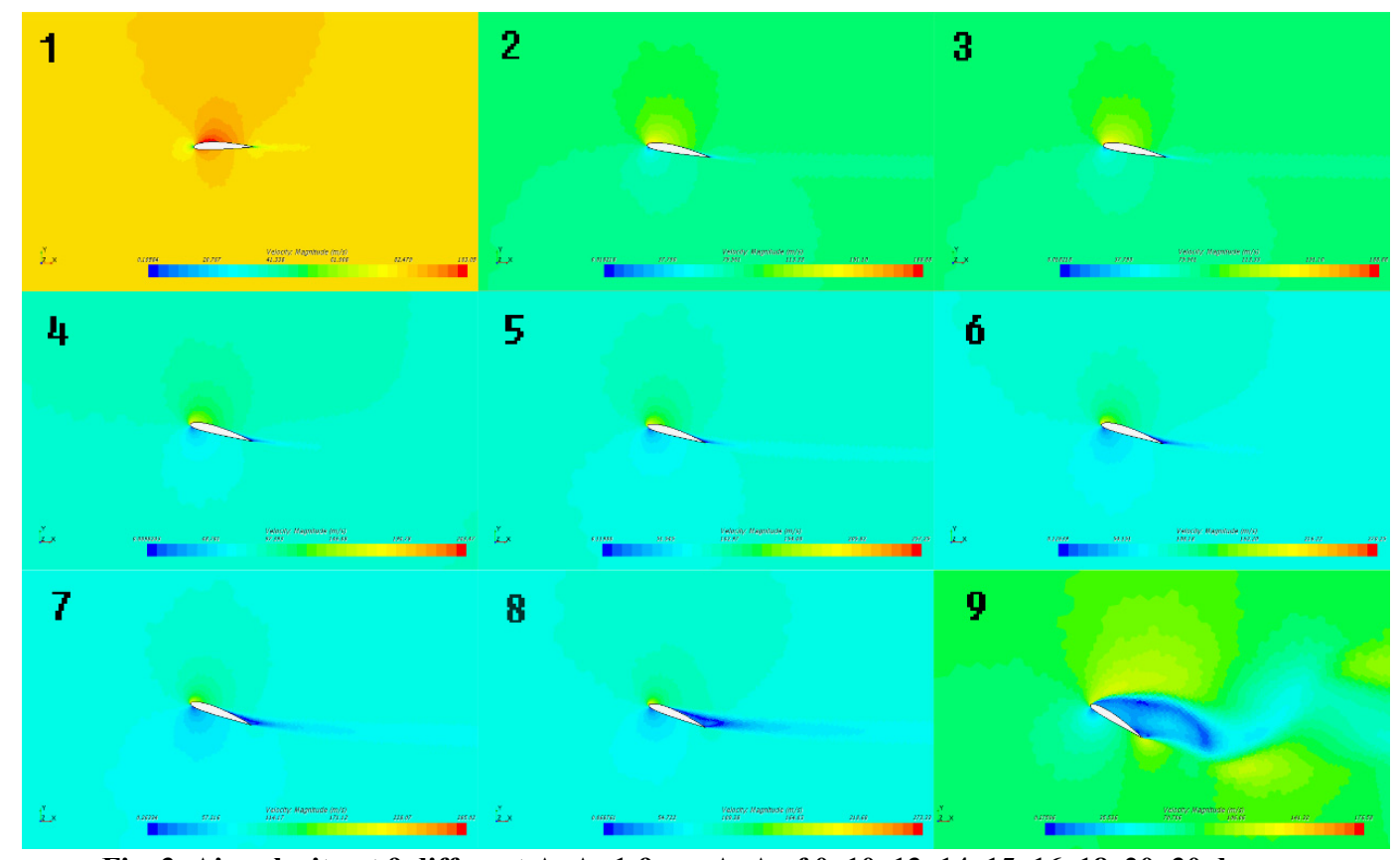

Fig. 3. Air velocity at 9 different AoA: 1-9 are AoA of 0, 10, 13, 14, 15, 16, 18, 20, 30 degrees 
Modern highly maneuverable aircraft like the F15 can perform high AoA maneuvers when the aircraft flies in one direction, the vertical axis (horizontal line) points in the other direction, and the lift vector may not match the aircraft's vertical axis (horizontal line) overlapping. The lift characteristics of the aircraft are linked to the AoA and flight speed. When the aircraft's AoA changes, the air flow around the airfoil also changes, which affects the lift value. Increasing flight speed when the AoA is constant can increase lift.

When the AoA increases to a dangerous value, the airflow on the airfoils will be disturbed and the lift will be lost. The airflow will start to separate from the left and right airfoils and cause side slip, eventually causing a stall. When entering a stall, the aircraft rotates around the vertical axis and constantly loses altitude. Some types of aircraft will pitch when they are spiraling.

\title{
Conclusions
}

In fluid dynamics, stall refers to a state in which the lift force generated by an airfoil suddenly decreases when the airfoil AoA increases to a certain level (a critical value is reached). Using STARCCM+ simulation, compared with the wind tunnel test data, the correct results of this angle for 2412 airfoil is 18 degrees. Before the aerodynamic AoA of the 2412 airfoil exceeds 18 degrees, the separation vortex does not exist or influences slightly. The lift force of the airfoil increases as the AoA increases. However, when the AoA exceeds 18 degrees, the separation vortex appears, the lift force of the airfoil becomes unstable and decreases, and the aircraft starts to stall. To maintain the best aerodynamic performance, the AoA in the range of 14 to 18 degrees is the best, and the AoA should not exceed 20 degrees. Once AoA is over 20 degrees, the pilot has to adjust the flight angle to maintain the lift force.

\section{References}

1. 王岩.从包头空难案看涉外航空损害赔偿的法律规避问题[J].法制与社会,2010(19):65-66.

2. Suo Shimei, Yu Min, Yu Xinyang, Fu Gui. (2018). Analysis of the causes of typical flight accidents [J]. Sichuan Building Materials. 44(09): 218-219.

3. A. Aghagoli, M. Sorin. (2019). Thermodynamic performance of a CO2 vortex tube based on 3D CFD flow analysis[J]. International Journal of Refrigeration. 108.

4. Tong-Qing G, Zhi-Liang L. A CFD/CSD Model for Transonic Flutter. Computers, Materials, \& Continua 2005; 2(2): 105-112.

\section{Дослідження ефектів турбулентності при зриві потоку повітря на профілі NACA 2412 з застосуванням моделі Spalart-Allmaras в програмі STARCCM+}

\author{
Чжесінь Ван, Юйвень Су \\ Анотація. Подано результати моделювання обтікання аеропрофілю NACA 2412 потоком повітря в програмі \\ StarCCM+. Виконано 9 груп порівняльних експериментів при кутах атаки: 0, 10, 13, 14, 15, 16, 18, 20, 30 градусів. \\ Аналіз повітряного потоку по верхній поверхні аеропрофілю дозволив одержати залежності між умовою вини- \\ кнення приєднаного вихру і кутом атаки і зміною кута атаки і підйомної сили. В знайденому діапазоні кута \\ атаки для зриву потоку визначено кут атаки з максимальним підйомним ефектом. \\ Ключові слова: зрив потоку, кут атаки, підйомна сила, NACA 2412, STARCCM+
}

